\title{
Thermomonas koreensis sp. nov., a mesophilic bacterium isolated from a ginseng field
}

Correspondence
Deok-Chun Yang
deokchunyang@yahoo.co.kr

\author{
Myung Kyum Kim, ${ }^{1}$ Wan-Taek Im, ${ }^{1}$ Jun-Gyo In, ${ }^{2}$ Sung-Hoon Kim ${ }^{3}$ \\ and Deok-Chun Yang ${ }^{1}$
}
${ }^{1,3}$ Department of Oriental Medicinal Material \& Processing, College of Life Science ${ }^{1}$, and Department of Oncology, Graduate School of East-West Medical Science ${ }^{3}$, Kyung Hee University, 1 Seocheon, Kiheung Yongin, Kyunggi 449-701, South Korea

${ }^{2}$ Biopia Co., Ltd, 383-4 Singal-ri, Kiheung Yongin, Kyunggi-do 449-598, South Korea
A Gram-negative, non-spore-forming, rod-shaped, motile bacterium, strain $\mathrm{KoO6}^{\top}$, was isolated from soil from a ginseng field in South Korea and was characterized in order to determine its taxonomic position. 16S rRNA gene sequence analysis revealed that strain $\mathrm{Ko}^{\top}{ }^{\top}$ belongs to the Gammaproteobacteria, and the highest levels of sequence similarity were with Thermomonas brevis LMG $21746^{\top}(98 \cdot 4 \%)$, Thermomonas fusca LMG $21737^{\top}(97 \cdot 7 \%)$, Thermomonas haemolytica A50-7-3 ${ }^{\top}(96 \cdot 5 \%)$ and Thermomonas hydrothermalis SGM-6 ${ }^{\top}(95 \cdot 8 \%)$. Chemotaxonomic data revealed that strain $\mathrm{KoO6}^{\top}$ possesses ubiquinone Q-8 and that the predominant fatty acids are $\mathrm{C}_{15: 0}$ iso, $\mathrm{C}_{11: 0}$ iso and $\mathrm{C}_{11: 0}$ iso $3-\mathrm{OH}$, all of which corroborated assignment of the strain to the genus Thermomonas. The results of DNA-DNA hybridization and physiological and biochemical tests clearly demonstrated that strain $\mathrm{KoO}^{\top}{ }^{\top}$ represents a distinct species. On the basis of these data, strain $\mathrm{KoO6}^{\top}\left(=\mathrm{KCTC} 12540^{\top}=\mathrm{NBRC} 101155^{\top}\right)$ should be classified as the type strain of a novel Thermomonas species, for which the name Thermomonas koreensis sp. nov. is proposed.
The genus Thermomonas was established by Busse et al. (2002) for four strains with high $G+C$ contents isolated from kaolin slurry, in which the strains were growing at temperatures as high as $50^{\circ} \mathrm{C}$; Thermomonas haemolytica is the type species. At the time of writing, there are four Thermomonas species with validly published names: Thermomonas haemolytica (Busse et al., 2002), Thermomonas brevis (Mergaert et al., 2003), Thermomonas fusca (Mergaert et al., 2003) and Thermomonas hydrothermalis (Alves et al., 2003).

In a series of studies, we used a culture-dependent method in attempts to isolate micro-organisms from a ginseng field in order to investigate the make-up of the microbial community. In this study, one strain was isolated from soil from a ginseng field in Daejeon (South Korea) and characterized by using polyphasic approaches. These polyphasic approaches, including phylogenetic analysis based on $16 \mathrm{~S}$ rRNA gene sequences, analysis of genomic relatedness and assessment of chemotaxonomic and phenotypic properties, were conducted to determine the precise taxonomic position of strain $\mathrm{Ko}_{0} 6^{\mathrm{T}}$. The results obtained in this study indicated that $\mathrm{Ko}^{\mathrm{T}}{ }^{\mathrm{T}}$ can be assigned as a member of the

The GenBank/EMBL/DDBJ accession number for the 16S rRNA gene sequence of strain $\mathrm{KoO6}^{\top}$ is $\mathrm{DQ} 154906$. genus Thermomonas but is clearly distinguishable from the Thermomonas species with validly published names.

Strain $\mathrm{Ko}^{\mathrm{T}}{ }^{\mathrm{T}}$ was isolated, using direct plating onto R2A agar (Difco), from soil from a ginseng field near Daechung Lake. Single colonies on these plates were purified by transferring them onto new plates and subjecting them to an additional incubation for 3 days at $30{ }^{\circ} \mathrm{C}$. The purified colonies were tentatively identified by means of partial $16 \mathrm{~S}$ rRNA gene sequences.

Cell morphology and motility were observed with a Nikon light microscope $(1000 \times$ magnification $)$, with the cells being allowed to grow for 3 days at $30^{\circ} \mathrm{C}$ on R2A agar. Gram reactions were conducted according to the non-staining method, as described by Buck (1982). Oxidase activity was evaluated using the oxidation of $1 \% p$-aminodimethylaniline oxalate. Catalase activity was determined by measuring bubble production after the application of a $3 \%(\mathrm{v} / \mathrm{v})$ hydrogen peroxide solution. Acid production from carbohydrates was assessed by using the procedures outlined by Cappuccino \& Sherman (2002). Growth at various temperatures $\left(4,15,25,30,37,42\right.$ and $\left.50{ }^{\circ} \mathrm{C}\right)$ was assessed on $\mathrm{R} 2 \mathrm{~A}$ agar, and growth at various $\mathrm{pH}$ values was assessed in R2A broth. Growth on nutrient agar, trypticase soy agar and MacConkey agar (Difco) was also evaluated at $30^{\circ} \mathrm{C}$. The API 20NE and API ID 32GN systems were employed 
in these tests, according to the recommendations of the manufacturer (bioMérieux).

Isoprenoid quinones were extracted with chloroform/ methanol $(2: 1, \mathrm{v} / \mathrm{v})$, purified using TLC and subsequently analysed by HPLC, as described previously (Collins \& Jones, 1981; Shin et al., 1996). For fatty acid methyl ester analyses, strain $\mathrm{Ko}_{0} 6^{\mathrm{T}}$ was allowed to grow on trypticase soy agar for $48 \mathrm{~h}$ at $30^{\circ} \mathrm{C}$ and then two loops of the well-grown cells were harvested. Fatty acid methyl esters were prepared, separated and identified with the Sherlock Microbial Identification System (MIDI) (Sasser, 1990). Total cellular lipids were extracted and analysed using TLC (Kim et al., 2005).

Genomic DNA of strain $\mathrm{Ko}^{\mathrm{T}}{ }^{\mathrm{T}}$ was extracted and purified with the Qiagen Genomic-tip system 100/G and then enzymically degraded into nucleosides, as described previously (Tamaoka \& Komagata, 1984; Mesbah et al., 1989). DNA-DNA hybridization was performed fluorometrically, according to the method developed by Ezaki et al. (1989), using photobiotin-labelled DNA probes and microdilution wells. Five replicate hybridizations were performed for each sample. The highest and lowest values obtained for each sample were excluded and the means of the remaining three values are quoted as DNA-DNA relatedness values.

Genomic DNA was extracted and purified with a genomic DNA isolation kit (Core Bio System). The 16S rRNA gene was amplified from the chromosomal DNA of strain $\mathrm{Ko}_{0} 6^{\mathrm{T}}$, using the universal bacterial primer set $9 \mathrm{~F}$ and $1512 \mathrm{R}$ (Weisburg et al., 1991); the purified PCR products were sequenced by Genotec (Daejeon, South Korea) (Kim et al., 2005). The full sequence of the $16 \mathrm{~S}$ rRNA gene was compiled with SeqMan software, and the 16S rRNA gene sequence of the test strain was edited using the BioEdit program (Hall, 1999). The 16S rRNA gene sequences of related taxa were obtained from GenBank. Multiple alignments were performed with the CLUSTAL $\mathrm{X}$ program (Thompson et al., 1997). Evolutionary distances were calculated using the Kimura two-parameter model (Kimura, 1983). The phylogenetic tree was constructed using the neighbour-joining method (Saitou \& Nei, 1987) in the MEGA 2 program (Kumar et al., 2001). Bootstrap analysis with 1000 replicates was also conducted to obtain confidence levels for the branches (Felsenstein, 1985). All of the species in the genus Thermomonas were included in the phylogenetic tree.

Strain $\mathrm{Ko}^{\mathrm{T}} 6^{\mathrm{T}}$ was cultured on $\mathrm{R} 2 \mathrm{~A}$ agar at $30^{\circ} \mathrm{C}$, yielding light-brownish and circular colonies. Strain $\mathrm{Ko} 06^{\mathrm{T}}$ was found to be an aerobic, Gram-negative, motile, rod-shaped bacterium. It was also determined as being able to grow at $20-37^{\circ} \mathrm{C}$, but it did not grow at 4 or $50^{\circ} \mathrm{C}$. The physiological characteristics of strain $\mathrm{Ko} 06^{\mathrm{T}}$ are summarized in the species description, and a comparison of distinguishing

Table 1. Differential phenotypic characteristics for strain $\mathrm{KoO6}^{\top}$ and related Thermomonas species

Taxa: 1, T. koreensis sp. nov. $\operatorname{Ko06}^{\mathrm{T}}$; 2, T. fusca ( $n=18$; Mergaert et al., 2003); 3, T. brevis ( $n=4$; Mergaert et al., 2003); 4, T. haemolytica ( $n=4$; Busse et al., 2002); 5, T. hydrothermalis ( $n=2$; Alves et al., 2003). All taxa are Gram-negative rods and are catalase- and oxidasepositive. Symbols: +, all positive; -, all negative; $(+)$, more than $60 \%$ of strains positive; $(-)$, more than $60 \%$ of strains negative; w, weakly positive; ND, not determined.

\begin{tabular}{|c|c|c|c|c|c|}
\hline Characteristic & 1 & 2 & 3 & 4 & 5 \\
\hline Motility & + & + & + & + & - \\
\hline Filamentous & - & + & - & + & - \\
\hline Cell size $(\mu \mathrm{m})$ & $0 \cdot 7 \times 3-4$ & $0 \cdot 7 \times 3-10$ & $0 \cdot 7 \times 3-10$ & $0 \cdot 5-0 \cdot 8 \times 1 \cdot 0-12 \cdot 5$ & $0 \cdot 6-0 \cdot 9 \times 2 \cdot 0-4 \cdot 0$ \\
\hline Brown pigment on $\mathrm{R} 2 \mathrm{~A}$ at $14-20^{\circ} \mathrm{C}$ & $\mathrm{w}$ & + & - & ND & $\mathrm{w}$ \\
\hline Optimum growth temperature $\left({ }^{\circ} \mathrm{C}\right)$ & 37 & $28-37$ & $28-37$ & $37-50$ & 50 \\
\hline Growth temperature range $\left({ }^{\circ} \mathrm{C}\right)$ & $20-37$ & $4-37$ & $4-37$ & $18-50$ & $30-60$ \\
\hline Nitrate reduction & + & + & + & - & + \\
\hline Nitrite reduction & - & + & + & - & + \\
\hline \multicolumn{6}{|l|}{ Enzyme activities } \\
\hline$\beta$-Glucosidase & + & - & - & - & + \\
\hline Lipase (C14) & - & $(-)$ & - & + & + \\
\hline Protease (gelatin hydrolysis) & + & + & + & $(+)$ & + \\
\hline Urease & - & - & - & + & - \\
\hline \multicolumn{6}{|l|}{ Assimilation tests } \\
\hline L-Malate & - & - & - & $(-)$ & - \\
\hline D-Glucose & + & - & + & - & + \\
\hline D-Maltose & + & - & + & - & + \\
\hline D-Mannose & - & - & + & - & - \\
\hline$N$-Acetylglucosamine & - & - & + & - & - \\
\hline DNA G $+\mathrm{C}$ content $(\mathrm{mol} \%)$ & $68 \cdot 3$ & $67 \cdot 6-68 \cdot 7$ & $68 \cdot 4$ & $67 \cdot 1-68 \cdot 7$ & $64 \cdot 7$ \\
\hline
\end{tabular}


characteristics with those of related type strains is shown in Table 1.

The cellular fatty acid profiles of strain $\mathrm{Ko}^{\mathrm{T}} 6^{\mathrm{T}}$ and related Thermomonas type strains are shown in Table 2. The major cellular fatty acid in strain $\mathrm{Ko}^{\mathrm{T}}{ }^{\mathrm{T}}$ was iso-pentadecanoic acid $\left(\mathrm{C}_{15: 0}\right.$ iso, $\left.53 \cdot 2 \%\right)$. Minor amounts of other isobranched fatty acids, $\mathrm{C}_{16: 0} 10$-methyl $(7 \cdot 0 \%), \mathrm{C}_{11: 0}$ iso 3$\mathrm{OH}(6 \cdot 7 \%), \mathrm{C}_{14: 0}(5 \cdot 3 \%), \mathrm{C}_{15: 0}$ anteiso $(4 \cdot 8 \%)$ and $\mathrm{C}_{11: 0}$ iso $(4 \cdot 6 \%)$ were present. $\mathrm{C}_{11: 0}$ iso $3-\mathrm{OH}(6 \cdot 7 \%)$ was the only hydroxy fatty acid found in strain $\mathrm{Ko}_{0} 6^{\mathrm{T}}$. The presence of iso-branched fatty acids, with $\mathrm{C}_{15: 0}$ iso as the major fatty acid, is characteristic of genera in the Xanthomonas branch, including Xanthomonas, Pseudoxanthomonas, Stenotrophomonas, Xylella and Luteimonas (Assih et al., 2002; Roumagnac et al., 2004; Yang et al., 2005). Significant differences in fatty acid profiles were found between different species of the genus Thermomonas.

The predominant quinone of strain $\mathrm{Ko} 06^{\mathrm{T}}$ was Q-8. The quinone system supported our assignment of strain $\mathrm{Ko}^{\mathrm{T}} \mathrm{6}^{\mathrm{T}}$ to the Xanthomonas branch, in which the majority of species (including Thermomonas species) also exhibit Q-8 as the predominant quinone.

Table 2. Cellular fatty acid profiles of strain $\mathrm{KoO6}^{\top}$ and related Thermomonas species

Taxa: 1, T. koreensis sp. nov. $\operatorname{Ko}^{\mathrm{T}}$; 2, T. fusca $(n=18$; Mergaert et al., 2003); 3, T. brevis $(n=4$; Mergaert et al., 2003); 4, T. haemolytica ( $n=3$; Mergaert et al., 2003); 5, T. hydrothermalis ( $n=2$; Alves et al., 2003). Values are percentages of total fatty acids. For unsaturated fatty acids, the position of the double bond is taken from the terminal methyl group of the carbon chain; cis isomers are indicated by the suffix $c$. tr, Trace.

\begin{tabular}{|c|c|c|c|c|c|}
\hline Fatty acid & 1 & 2 & 3 & 4 & 5 \\
\hline \multicolumn{6}{|c|}{ Saturated fatty acids } \\
\hline $10: 0$ iso & & & & & $0 \cdot 5$ \\
\hline $11: 0$ anteiso & & & & & $0 \cdot 2-0 \cdot 3$ \\
\hline $11: 0$ iso & $4 \cdot 6$ & $5 \cdot 8-9 \cdot 1$ & $7 \cdot 2-10 \cdot 1$ & $7 \cdot 9-8 \cdot 4$ & $4 \cdot 8-5 \cdot 0$ \\
\hline $12: 0$ iso & & & & & $0 \cdot 4$ \\
\hline $13: 0$ iso & $3 \cdot 2$ & $0 \cdot 6-4 \cdot 6$ & $\operatorname{tr}$ & $\operatorname{tr}$ & $0 \cdot 6-1 \cdot 0$ \\
\hline $14: 0$ & $5 \cdot 3$ & $1 \cdot 4-2 \cdot 8$ & $1 \cdot 1-1 \cdot 3$ & $\operatorname{tr}$ & $1 \cdot 4-1 \cdot 7$ \\
\hline $14: 0$ iso & & $0 \cdot 9-8 \cdot 1$ & $\operatorname{tr}$ & $2 \cdot 9-5 \cdot 2$ & $4 \cdot 0-5 \cdot 3$ \\
\hline $15: 0$ & & & & & $0 \cdot 7-0 \cdot 8$ \\
\hline $15: 0$ anteiso & $4 \cdot 8$ & $0 \cdot 3-2 \cdot 2$ & $\operatorname{tr}$ & $\operatorname{tr}$ & $3 \cdot 7-4 \cdot 0$ \\
\hline $15: 0$ iso & $53 \cdot 2$ & $30 \cdot 9-44 \cdot 8$ & $45 \cdot 3-48 \cdot 7$ & $49 \cdot 5-55 \cdot 2$ & $37 \cdot 7-41 \cdot 9$ \\
\hline $16: 0$ & $3 \cdot 7$ & $0 \cdot 7-2 \cdot 3$ & $2 \cdot 6-3 \cdot 0$ & $\operatorname{tr}$ & $2 \cdot 3-3 \cdot 3$ \\
\hline 16:0 10-methyl & $7 \cdot 0$ & & & & \\
\hline $16: 0$ iso & $3 \cdot 9$ & $0 \cdot 6-11 \cdot 2$ & $\operatorname{tr}$ & $4 \cdot 3-7 \cdot 6$ & $11 \cdot 4-15 \cdot 1$ \\
\hline $17: 0$ anteiso & & & & & $0 \cdot 2-0 \cdot 6$ \\
\hline $17: 0$ iso & & $0 \cdot 8-2 \cdot 3$ & $2 \cdot 2-2 \cdot 8$ & $1 \cdot 5-2 \cdot 1$ & $4 \cdot 1-4 \cdot 7$ \\
\hline \multicolumn{6}{|c|}{ Unsaturated fatty acids } \\
\hline $14: 1 \omega 5 c$ & & & & & $0 \cdot 6-0 \cdot 8$ \\
\hline $15: 1$ iso $F$ & $4 \cdot 3$ & $2 \cdot 5-5 \cdot 9$ & $1 \cdot 4-1 \cdot 6$ & $3 \cdot 0-3 \cdot 7$ & $2 \cdot 5-3 \cdot 3$ \\
\hline $15: 1 \omega 6 c$ & & & & & $0 \cdot 8-0 \cdot 9$ \\
\hline $16: 1$ iso $\mathrm{H}$ & & & & & $0 \cdot 5$ \\
\hline $16: 1 \omega 9 c$ & & & & & $0 \cdot 5-0 \cdot 6$ \\
\hline $17: 1$ iso $\omega 9 c$ & & $14 \cdot 4-23 \cdot 3$ & $20 \cdot 1-22 \cdot 5$ & $11 \cdot 3-12 \cdot 3$ & $0-5 \cdot 3$ \\
\hline \multicolumn{6}{|c|}{ Hydroxy fatty acids } \\
\hline $11: 0$ iso $3-\mathrm{OH}$ & $6 \cdot 7$ & $6 \cdot 5-10 \cdot 5$ & $7 \cdot 8-11 \cdot 2$ & $9 \cdot 2-10 \cdot 0$ & $6 \cdot 3-6 \cdot 5$ \\
\hline $12: 0$ iso $3-\mathrm{OH}$ & & & & & $0 \cdot 4$ \\
\hline $16: 03-\mathrm{OH}$ & & & & & $0-0 \cdot 3$ \\
\hline \multicolumn{6}{|c|}{ Summed features ${ }^{\star}$} \\
\hline SF2 & & & & & $0 \cdot 6-0 \cdot 7$ \\
\hline SF4 & $3 \cdot 3$ & $2 \cdot 7-7 \cdot 0$ & $2 \cdot 8-3 \cdot 1$ & $\operatorname{tr}$ & $4 \cdot 6-4 \cdot 8$ \\
\hline SF5 & & & & & $0 \cdot 1-0 \cdot 2$ \\
\hline
\end{tabular}

${ }^{*}$ Summed features contain fatty acids that could not be separated by GLC with the Microbial Identification

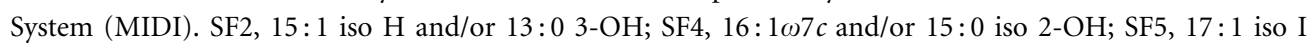
and/or 17:1 anteiso B. 


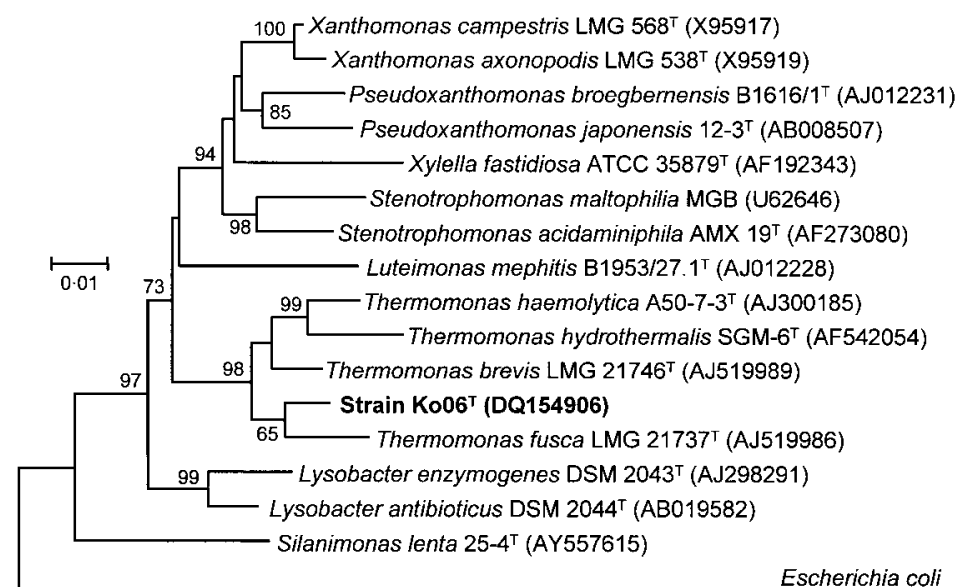

ATCC $11775^{\top}(X 80725)$
Fig. 1. Phylogenetic tree, based on $16 \mathrm{~S}$ rRNA gene sequences, showing the phylogenetic relationships between strain $\mathrm{KoO6}^{\top}$, all species of Thermomonas and members of related genera in the Xanthomonas branch. The neighbour-joining method was used. Bootstrap values higher than $66 \%$ are shown. Bar, 0.01 substitutions per nucleotide position.
The $16 \mathrm{~S}$ rRNA gene sequence of strain $\mathrm{Ko}^{\mathrm{T}} 6^{\mathrm{T}}$ was found to be a continuous stretch of $1474 \mathrm{nt}$. The 16S rRNA gene sequences of related taxa were obtained from GenBank. Strain $\mathrm{Ko}^{\mathrm{T}}{ }^{\mathrm{T}}$ was determined as belonging to the Gammaproteobacteria, and the highest levels of sequence similarity were with T. brevis LMG $21746^{\mathrm{T}}(98 \cdot 4 \%)$, T. fusca LMG $21737^{\mathrm{T}}(97 \cdot 7 \%)$, T. haemolytica A50-7-3 ${ }^{\mathrm{T}}(96 \cdot 5 \%)$ and T. hydrothermalis SGM- $6^{\mathrm{T}}(95 \cdot 8 \%)$. In the phylogenetic tree (Fig. 1), strain $\mathrm{Ko}^{\mathrm{T}}{ }^{\mathrm{T}}$ clearly belongs to the Thermomonas lineage, as evident from the high bootstrap value.

The G $+\mathrm{C}$ content of the genomic DNA of strain $\mathrm{Ko} 06^{\mathrm{T}}$ was found to be $68 \cdot 3 \mathrm{~mol} \%$. Strain $\mathrm{Ko}^{\mathrm{T}}{ }^{\mathrm{T}}$ exhibited a relatively low level of DNA-DNA relatedness to the type strains T. fusca LMG $21737^{\mathrm{T}}(27 \%)$, T. brevis LMG $21746^{\mathrm{T}}(13 \%)$, T. haemolytica $\mathrm{A} 50-7-3^{\mathrm{T}}(16 \%)$ and $T$. hydrothermalis SGM-6 ${ }^{\mathrm{T}}(19 \%)$. The level of DNA-DNA hybridization to related type strains was therefore less than $70 \%$ (Stackebrandt \& Goebel, 1994), a value which is regarded as the threshold for delineating a genomic species. Our results therefore support the classification of strain $\mathrm{Ko} 06^{\mathrm{T}}$ within a separate, previously unrecognized species. The results of our polyphasic analysis support the recognition of a novel species within the genus Thermomonas, for which the name Thermomonas koreensis sp. nov. is proposed.

\section{Description of Thermomonas koreensis sp. nov.}

Thermomonas koreensis sp. nov. (ko.re.en'sis. N.L. fem. adj. koreensis pertaining to Korea, the location of the soil sample from which the type strain was isolated).

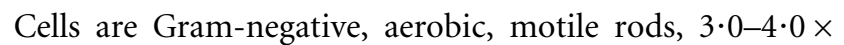
$0 \cdot 7 \mu \mathrm{m}$ in size after growth on R2A agar for 3 days at $30^{\circ} \mathrm{C}$. The optimal growth temperature and $\mathrm{pH}$ are $37^{\circ} \mathrm{C}$ and $\mathrm{pH} 8 \cdot 0-9 \cdot 0$, and grow is observed at a salt concentration of $3 \%$. Catalase- and oxidase-positive. Shows $\beta$-glucosidase and protease (gelatin hydrolysis) activity and does not show arginine dihydrolase, urease or $\beta$-galactosidase (PNPG) activity. Does not produce any biopolymerhydrolysing enzymes such as cellulase, chitinase, DNase, lipase or xylanase. Assimilates D-glucose, D-maltose, acetate, L-alanine, propionate, 3-hydroxybutyrate, L-proline and does not assimilate L-arabinose, D-mannose, D-mannitol, $\mathrm{N}$-acetylglucosamine, gluconate, caprate, adipate, malate, citrate, phenylacetate, L-rhamnose, D-ribose, myo-inositol, D-sucrose, itaconate, suberate, malonate, lactate, 5-ketogluconate, glycogen, 3-hydroxybenzoate, L-serine, salicin, Dmelibiose, L-fucose, D-sorbitol, valerate, L-histidine, 2-ketogluconate or 4-hydroxybenzoate. DNA G+C content is $68.3 \mathrm{~mol} \%$ (as determined by HPLC). Q-8 is the predominant quinone. The major cellular fatty acid is $\mathrm{C}_{15: 0}$ iso, $(53 \cdot 2 \%)$. Other phenotypic characteristics, such as substrates utilized and enzymes produced, are summarized in Table 1.

The type strain, $\mathrm{Ko} 6^{\mathrm{T}}\left(=\mathrm{KCTC} 12540^{\mathrm{T}}=\mathrm{NBRC} 101155^{\mathrm{T}}\right)$, was isolated from soil from a ginseng field near Daechung Lake in Daejeon, South Korea.

\section{Acknowledgements}

This work was supported by a grant (code MB-14) from the BioGreen 21 Program of the Rural Development Administration, Republic of Korea.

\section{References}

Alves, M. P., Rainey, F. A., Nobre, M. F. \& da Costa, M. S. (2003). Thermomonas hydrothermalis sp. nov., a new slightly thermophilic $\gamma$ proteobacterium isolated from a hot spring in central Portugal. Syst Appl Microbiol 26, 70-75.

Assih, E. A., Ouattara, A. S., Thierry, S., Cayol, J.-L., Labat, M. \& Macarie, H. (2002). Stenotrophomonas acidaminiphila sp. nov., a strictly aerobic bacterium isolated from an upflow anaerobic sludge blanket (UASB) reactor. Int J Syst Evol Microbiol 52, 559-568.

Buck, J. D. (1982). Nonstaining (KOH) method for determination of Gram reactions of marine bacteria. Appl Environ Microbiol 44, 992-993.

Busse, H.-J., Kämpfer, P., Moore, E. R. B. \& 7 other authors (2002). Thermomonas haemolytica gen. nov., sp. nov., a $\gamma$-proteobacterium from kaolin slurry. Int J Syst Evol Microbiol 52, 473-483. 
Cappuccino, J. G. \& Sherman, N. (2002). Microbiology: a Laboratory Manual, 6th edn. Menlo Park, CA: Benjamin Cummings Science Publishing.

Collins, M. D. \& Jones, D. (1981). Distribution of isoprenoid quinone structural types in bacteria and their taxonomic implications. Microbiol Rev 45, 316-354.

Ezaki, T., Hashimoto, Y. \& Yabuuchi, E. (1989). Fluorometric deoxyribonucleic acid-deoxyribonucleic acid hybridization in microdilution wells as an alternative to membrane filter hybridization in which radioisotopes are used to determine genetic relatedness among bacterial strains. Int J Syst Bacteriol 39, 224-229.

Felsenstein, J. (1985). Confidence limit on phylogenies: an approach using the bootstrap. Evolution 39, 783-791.

Hall, T. A. (1999). BioEdit: a user-friendly biological sequence alignment editor and analysis program for Windows 95/98/NT. Nucleic Acids Symp Ser 41, 95-98.

Kim, M. K., Im, W.-T., Ohta, H., Lee, M. \& Lee, S.-T. (2005). Sphingopyxis granuli sp. nov., a $\beta$-glucosidase-producing bacterium in the family Sphingomonadaceae in $\alpha-4$ subclass of the Proteobacteria. J Microbiol 43, 152-157.

Kimura, M. (1983). The Neutral Theory of Molecular Evolution. Cambridge: Cambridge University Press.

Kumar, S., Tamura, K., Jakobsen, I.-B. \& Nei, M. (2001). MEGA2: molecular evolutionary genetics analysis software. Bioinformatics 17, 1244-1245.

Mergaert, J., Cnockaert, M. C. \& Swings, J. (2003). Thermomonas fusca sp. nov. and Thermomonas brevis sp. nov., two mesophilic species isolated from a denitrification reactor with poly( $\varepsilon$-caprolactone) plastic granules as fixed bed, and emended description of the genus Thermomonas. Int J Syst Evol Microbiol 53, 1961-1966.

Mesbah, M., Premachandran, U. \& Whitman, W. B. (1989). Precise measurement of the $\mathrm{G}+\mathrm{C}$ content of deoxyribonucleic acid by high-performance liquid chromatography. Int J Syst Bacteriol 39, 159-167.

Roumagnac, P., Gagnevin, L., Gardan, L., Sutra, L., Manceau, C., Dickstein, E. R., Jones, J. B., Rott, P. \& Pruvost, O. (2004). Polyphasic characterization of xanthomonads isolated from onion, garlic and Welsh onion (Allium spp.) and their relatedness to different Xanthomonas species. Int J Syst Evol Microbiol 54, 15-24.

Saitou, N. \& Nei, M. (1987). The neighbor-joining method: a new method for reconstructing phylogenetic trees. Mol Biol Evol 4, 406-425.

Sasser, M. (1990). Identification of bacteria by gas chromatography of cellular fatty acids. Technical Note 101. Newark, DE: MIDI.

Shin, Y. K., Lee, J.-S., Chun, C. O., Kim, H.-J. \& Park, Y.-H. (1996). Isoprenoid quinone profiles of the Leclercia adecarboxylata KCTC $1036^{\mathrm{T}}$. J Microbiol Biotechnol 6, 68-69.

Stackebrandt, E. \& Goebel, B. M. (1994). Taxonomic note: a place for DNA-DNA reassociation and 16S rRNA sequence analysis in the present species definition in bacteriology. Int J Syst Bacteriol 44, 846-849.

Tamaoka, J. \& Komagata, K. (1984). Determination of DNA base composition by reversed phase high-performance liquid chromatography. FEMS Microbiol Lett 25, 125-128.

Thompson, J. D., Gibson, T. J., Plewniak, F., Jeanmougin, F. \& Higgins, D. G. (1997). The CLUSTAL_X windows interface: flexible strategies for multiple sequence alignment aided by quality analysis tools. Nucleic Acids Res 25, 4876-4882.

Weisburg, W. G., Barns, S. M., Pelletier, D. A. \& Lane, D. J. (1991). $16 \mathrm{~S}$ ribosomal DNA amplification for phylogenetic study. J Bacteriol 173, 697-703.

Yang, D.-C., Im, W.-T., Kim, M. K. \& Lee, S.-T. (2005). Pseudoxanthomonas koreensis sp. nov. and Pseudoxanthomonas daejeonensis sp. nov. Int J Syst Evol Microbiol 55, 787-791. 